\title{
INFORMATION ON BLACK-FOOTED FERRET BIOLOGY COLLECTED WITHIN THE FRAMEWORK OF FERRET CONSERVATION
}

\author{
Dean E. Biggins ${ }^{1}$
}

\begin{abstract}
Once feared to be extinct, black-footed ferrets (Mustela nigripes) were rediscovered near Meeteetse, Wyoming, in 1981, resulting in renewed conservation and research efforts for this highly endangered species. A need for information directly useful to recovery has motivated much monitoring of ferrets since that time, but field activities have enabled collection of data relevant to broader biological themes. This special feature is placed in a context of similar books and proceedings devoted to ferret biology and conservation. Articles include general observations on ferrets, modeling of potential impacts of ferrets on prairie dogs (Cynomys spp.), discussions on relationships of ferrets to prairie dog habitats at several spatial scales (from individual burrows to patches of burrow systems) and a general treatise on the status of black-footed ferret recovery.

RESUMEN.-Cuando se temía que ya hubieran desaparecido, se volvieron a descubrir hurones de patas negras (Mustela nigripes) cerca de Meeteetse, Wyoming en 1981, lo que resultó en la renovación de esfuerzos por la conservación e investigación de esta especie en peligro crítico de extinción. Desde entonces, la necesidad de información directamente útil para su recuperación ha sido la motivación para gran parte del monitoreo de los hurones; sin embargo, las actividades en el campo han permitido la colección de información relevante para contextos biológicos más amplios. Esta edición especial se ubica en el contexto de los libros y memorias similares que se han dedicado a la biología y conservación de los hurones. Este número incluye descripciones de observaciones generales sobre los hurones, modelos de los impactos potenciales de los hurones sobre los perros llaneros (Cynomys), discusiones de las relaciones entre los hurones y los hábitats de los perros llaneros en diferentes escalas espaciales desde madrigueras individuales a áreas con sistemas de madrigueras, y también un tratado general del estatus de la recuperación del hurón.
\end{abstract}

Black-footed ferrets (Mustela nigripes) were feared to be extinct by the late 1970s, when ferrets were no longer confirmed to exist in wild habitats and the last animal of the first captive breeding attempt died at Patuxent Wildlife Research Center in Maryland. Rediscovery of ferrets near Meeteetse, Wyoming, in 1981 gave conservationists renewed hope for saving this species by learning more about its biology and implementing further conservation efforts (Biggins et al. 2011b). Several years of intensive work at Meeteetse resulted in rapid accumulation of new information and ideas for recovery. As a result, a group of black-footed ferret researchers joined with editors of the Great Basin Naturalist to publish a collection of manuscripts on ferret biology. It became Great Basin Naturalist Memoirs 8 (Wood 1986), the first such collection of papers to be published in a peer-reviewed volume. Other bound collections of papers on ferrets have since been published as books, workshop proceedings, and symposia proceed- ings (Fig. 1). These volumes have become standard references for those generally interested in ferrets and those seriously involved in the ferret recovery effort. Hence, assembling these papers under common covers where they are easily accessible to managers and conservationists seems highly useful (Biggins et al. 2011b).

For the collection of papers herein, we examined data sets and ideas that we thought would be particularly suitable for publication in a regional journal and could contribute to a better understanding of black-footed ferrets and their conservation. We recently celebrated the 30th anniversary of the rediscovery of ferrets, and the data collection for papers in this feature span almost the entire period. These papers often consider data that were collected peripherally to conservation activities or to ferret research with other focused objectives. Some describe details omitted from other published papers because of space limitations, and others reflect descriptive biology. For example, the data on digging behaviors of ferrets in

${ }^{1}$ U.S. Geological Survey, Fort Collins Science Center, 2150 Centre Avenue, Building C, Fort Collins, CO 80525. E-mail: dean_biggins@usgs.gov 
the ancestral Meeteetse population (Biggins et al. 2012a) were collected during radiotelemetric studies of ferret activity patterns, movements, and space use (Biggins et al. 1986, Fagerstone and Biggins 2011). Similarly, data on ferret use of burrow systems (Biggins 2012) were collected during investigations on effects of rearing conditions on behaviors and survival of reintroduced ferrets (Biggins et al. 1998, 1999). Other detailed studies of ferrets and their habitat (Eads et al. 2011a, 2011b) provided opportunity to evaluate the effects of moonlight and season on the efficiency of detecting ferrets using spotlights (Eads et al. 2012c); they also provided several fascinating observations on ferret behaviors (Eads 2012).

Over the years, the relationships among habitat attributes, resources, and black-footed ferrets have been examined at broad scales for management purposes (Forrest et al. 1985, Houston et al. 1986, Miller et al. 1988). Indeed, overall density of burrow openings can be correlated to prairie dog biomass to provide a useful measure of the capability of a complex of colonies to support black-footed ferrets, especially in a comparative sense (Biggins et al. 1993, 2006). When one looks casually across a prairie dog colony, the typical impression is a rather uniform environment dominated by mounds of soil. On closer examination, however, considerable variation in spacing of burrow entrances becomes apparent, and even closer study reveals variation in types of burrow structures. The mosaic of clustered burrows of various types is the environmental scale that is likely perceived by individual ferrets (Eads et al. 2011a, 2011b) and it is the topic of investigation for several papers in this issue (Chipault et al. 2012, Eads et al. 2012b). The home range paper of Livieri and Anderson (2012) also considers the space used by individual ferrets, with attention to the amount of overlap in areas of use.

A unique feature of this special feature is its emphasis on the burrow-oriented lifestyle of black-footed ferrets. The majority of the previous behavioral studies of black-footed ferrets-carnivores that spend $90 \%$ of their time in burrows (Biggins et al. 1986)_describe aboveground behaviors related to activity patterns, space use, home range, habitat selection, movements, and interactions with other species. The paucity of information on subterranean activities of ferrets may be partly the result of our anthropocentric difficulties in understanding the sensory perceptions of ferrets and their underground lives, but it also stems from the difficulty in designing studies that can investigate behaviors of animals belowground without disturbing the subjects. Studies of burrow use and modification reported herein relied largely on indirect evidence and radiotelemetry, and much of the attendant discussion of causes and interspecific interactions must remain speculative. Burrow-related topics of this issue include the following: use of multi-opening burrow systems by ferrets (Biggins 2012), ferret digging on black-tailed prairie dog (Cynomys ludovicianus) colonies in summer (Eads et al. 2012a), ferret digging on white-tailed prairie $\operatorname{dog}(C$. leucurus) colonies in winter (Biggins et al. 2012a), and the prairie dog behavior of plugging burrows at the ground surface (Eads and Biggins 2012) or belowground (Biggins et al. $2012 b$ ) in response to ferret presence.

A burrow-dwelling lifestyle has additional important ramifications. The relatively cool and stable temperatures and humidity of burrows seem favorable for the bacterium that causes plague (Yersinia pestis) and the fleas that are its vectors. This imported pathogen (Y. pestis invaded North America ca. 1900) is not only devastating to prairie dogs, which are prey of ferrets, but it is also lethal to the ferrets themselves. The latter fact was not known when Archie Carr provided his interpretation of the plague episode that had just begun at Meeteetse (Carr 1986) in the introduction to the inaugural collection of ferret papers mentioned above (Wood 1986; Fig. 1). Since then, epizootic plague has caused complete losses of some ferret habitat, and even the relatively low incidence of $Y$. pestis associated with enzootic plague apparently has reduced prairie dog survival rates by about $40 \%$ (Biggins et al. 2010). Even more surprisingly, the effect of enzootic plague seems amplified in ferrets, reducing their survival rates by $240 \%$ (Matchett et al. 2010). Plague is now widely regarded as the most serious biological impediment to ferret recovery (Jachowski and Lockhart 2009), and a recent symposium underscored the ecological threats posed by plague (Antolin et al. 2010). Some prairie dog complexes are maintained and remain occupied by ferrets only with intensive plague management using deltamethrin powder annually applied to burrows to kill the fleas 


\section{$\checkmark$ Timing of field studies reported in this volume}

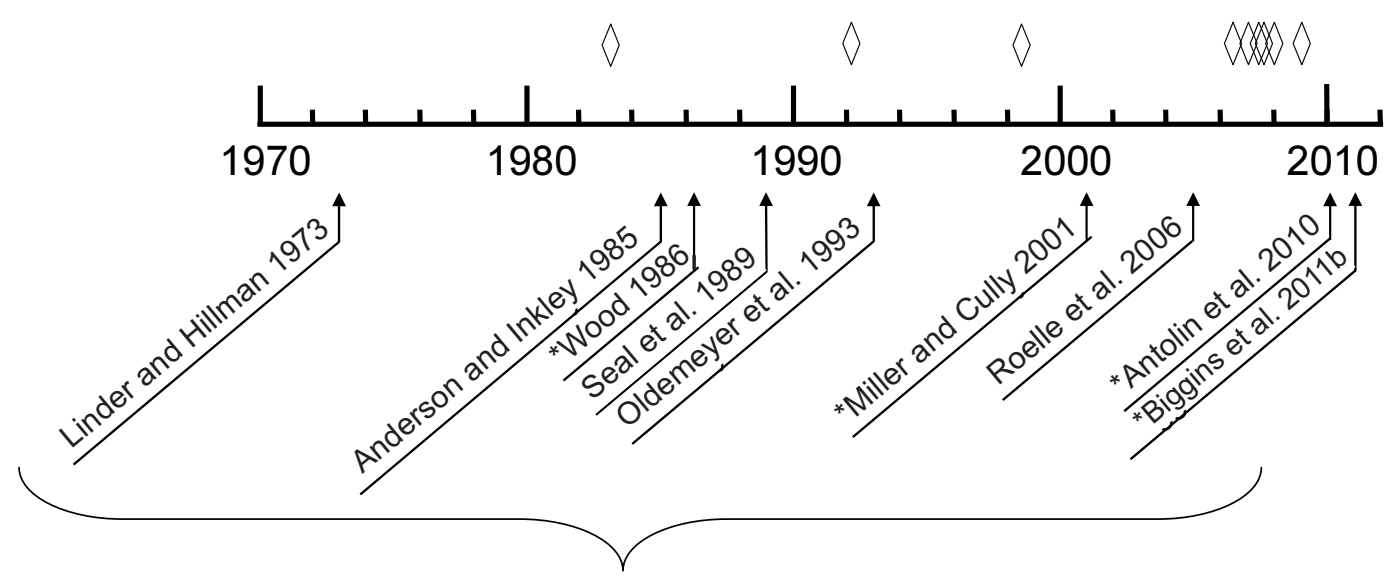

Other black-footed ferret workshops, symposia, special editions, special sections $\left({ }^{*}=\right.$ journal publications $)$

Fig. 1. Timeline illustrating black-footed ferret symposia, workshops, special publications, and the field studies summarized in this volume.

that transmit the bacteria. Although a vaccine for ferrets has been developed and has proven successful at protecting ferrets from plague (Rocke et al. 2004), it must be administered via injection, a difficult and time-consuming effort, and it does nothing toward protecting the prey base and habitat that ferrets depend on for continued survival. Experiments are now underway to field test an oral plague vaccine for prairie dogs that may make plague management easier in prairie dogs and ultimately ferrets (Rocke et al. 2010).

Although plague is considered by many to be the most serious biological impediment to recovery, other factors also contribute to the precarious status of black-footed ferrets in the wild. Large-scale habitat losses caused by cropland conversions and the general intolerance of prairie dogs by humans also impede recovery (Miller and Reading 2012). Despite these problems, there is hope for the future. Black-footed ferret recovery has progressed significantly, even under the dark shadows of plague and prairie dog persecution by man. The captive breeding program maintains about 200-300 breeding-age ferrets that produce a crop of kits each year for replacement and reintroduction. Reintroductions have become more efficient (Biggins et al. 1998, 1999), and direct translocations of ferrets are highly successful (Biggins et al. 2011a). More than 3000 ferrets have been released at 19 sites in 10 states (including Saskatchewan, Canada, and Chihuahua, Mexico) resulting in combined populations of about 700-800 free-ranging ferrets in summer of 2010 (Fig. 2). With the potential addition of an oral plague vaccine for prairie dogs as a management tool and an incentive program to encourage private landowners to maintain prairie dog colonies, it may be possible to bring the ferret recovery program one step closer to achieving its goals.

\section{ACKNOWLEDGMENTS}

A good measure of credit for the successes of black-footed ferret recovery efforts is due to the Wyoming Game and Fish Department, the U.S. Fish and Wildlife Service's Black-footed Ferret Conservation Center, and multiple zoos for producing ferrets that have been reintroduced to the wild over the past 25 years. The National Zoo (Front Royal, VA), Henry Doorly Zoo (Omaha, NB), Louisville Zoo (Louisville, KY), Toronto Zoo (Toronto, Ontario, Canada), Cheyenne Mountain Zoo (Colorado Springs, CO), and Phoenix Zoo (Phoenix, AZ) are commended for generating their own funds to 


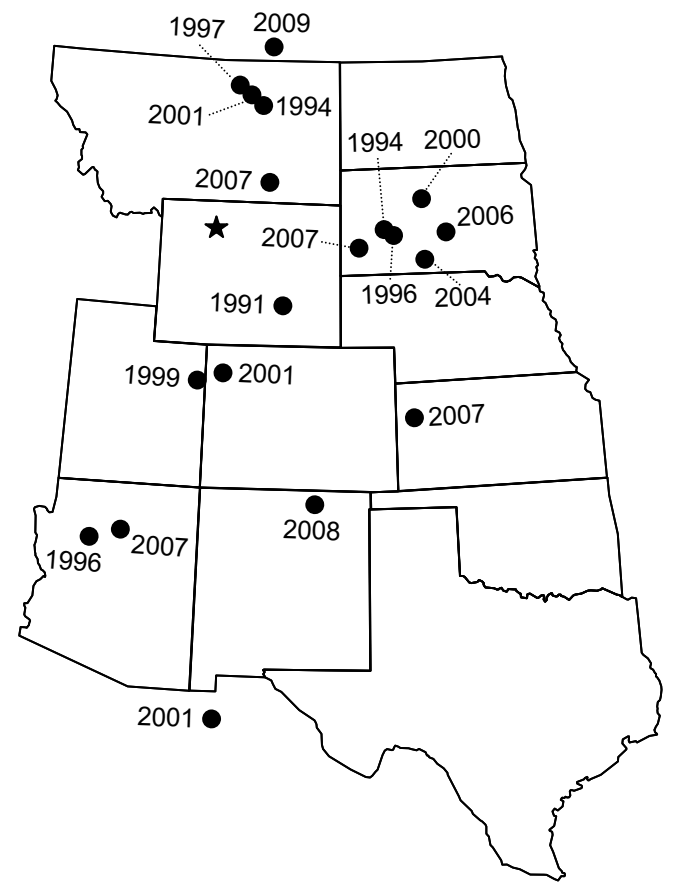

- Location of the extirpated ancestral population of black-footed ferrets

Fig. 2. States where black-footed ferrets likely were historically present and sites where ferrets have been released. Numbers designate year of first release.

support ferret conservation. Reintroduction of ferrets began with captive production of the animals, but tremendous effort was required at many other levels to finally reestablish the multiple populations of free-ranging animals (Fig. 2). The individuals directly involved now number in the hundreds, and they work within state work groups and represent many state and federal agencies, as well as private organizations. To name all individuals who have put their hearts and lives into ferret conservation unfortunately is not possible here (but visit the web site http://www.prairiewildlife.org/). Sadly, some members of our team from the postMeeteetse era are no longer with us but remain alive in our memories. These include the following: William Russell, George E. Menkins Jr., Ulysses Seal, Stanley H. Anderson, Donna Zeiler, JoGayle Dillon Howard, Lucille Hogg, E. Tom Thorne, Elizabeth S. Williams, and Joe Truett. Their contributions were considerable, and they are missed. Finally, it also seems fitting to pay tribute to Shep, the dog owned by John and Lucille Hogg, who by killing an individual ferret near Meeteetse in 1981 gave life to the species.

On a brighter note, the collaboration and hard work of 18 colleagues who combined efforts to create the papers in this special feature is noteworthy and appreciated. Erin Lehmer graciously agreed to serve as a guest associate editor and shepherd the papers through the submission and review process. WNAN editor-in-chief, Mark C. Belk, encouraged the creation of this special feature and showed extraordinary patience with those of us (especially me) whose progress was always slower than planned. Sincere thanks are thus extended to Mark and to Janene Auger, Toni Pilcher, Megan Gebhard, and Carly Huchendorf for attending to the numerous details associated with creating this feature. The authors of papers herein appreciate the continued existence of regional natural history journals where observational biology can be published.

\section{Literature Cited}

Anderson, S.H., AND D.B. InKLey, Editors. 1985. Proceedings of the Black-footed Ferret Workshop. Wyoming Game and Fish Department, Cheyenne, WY.

Antolin, M.F., D.E. Biggins, And P. Gober. 2010. Symposium on the ecology of plague and its effects on wildlife: a model for translational research. VectorBorne and Zoonotic Diseases 10(1):3-5.

BIGGINS, D.E. 2012. Use of multi-opening burrow systems by black-footed ferrets. Western North American Naturalist 72:134-139.

Biggins, D.E., J.L. Godbey, K.L. Gage, L.G. Carter, AND J.A. Montenieri. 2010. Vector control improves survival of three species of prairie dogs (Cynomys) in areas considered enzootic for plague. Vector-Borne and Zoonotic Diseases 10(1):17-26.

Biggins, D.E., J.L. Godbey, L.H. Hanebury, B. Luce, P.E. Marinari, M.R. MatchetT, and A. Vargas. 1998. The effect of rearing methods on survival of reintroduced black-footed ferrets. Journal of Wildlife Management 62:643-653.

Biggins, D.E., J.L. Godbey, B.M. Horton, And T.M. LIVIERI. 2011a. Movements and survival of blackfooted ferrets associated with an experimental translocation in South Dakota. Journal of Mammalogy 92: 742-750.

Biggins, D.E., L.R. Hanebury, and K.A. Fagerstone. 2012a. Digging behaviors of radio-tagged blackfooted ferrets near Meeteetse, Wyoming, 1981-1984. Western North American Naturalist 72:148-157.

Biggins, D.E., J.M. LOCKHART, AND J.L.Godbey. 2006. Evaluating habitat for black-footed ferrets: revision of a former model. Pages 143-150 in J.E. Roelle, B.J. Miller, J.L. Godbey, and D.E. Biggins, editors, Recovery of the black-footed ferret-progress and continuing challenges. U.S. Geological Survey Scientific Investigations Report 2005-5293. 
Biggins, D.E., T.M. Livieri, and S.W. Breck. 2011b. The interface between black-footed ferret research and operational conservation. Journal of Mammalogy 92: 699-704.

Biggins, D.E., B, Miller, L. Hanebury, R. Oakleaf, A. Farmer, R. Crete and A. Dood. 1993. A technique for evaluating black-footed ferret habitat. Pages 73-88 in J. Oldemeyer, D. Biggins, B. Miller, and R. Crete, editors, Management of prairie dog complexes for reintroduction of the black-footed ferret. U.S. Fish and Wildlife Service, Biological Report 1993-13.

Biggins, D.E., S. Ramakrishnan, A.R. Goldberg, and D.A. EADS. 2012b. Black-footed ferrets and recreational shooting influence the attributes of blacktailed prairie dog burrows. Western North American Naturalist 72:158-171.

Biggins, D.E., M.H. Schroeder, S.C. Forrest, And L. RichaRDSON. 1986. Activity of radio-tagged blackfooted ferrets. Great Basin Naturalist Memoirs 8: 135-140.

Biggins, D.E., A. Vargas, J.L. Godbey, and S.H. AnderSON. 1999. Influence of prerelease experience on reintroduced black-footed ferrets (Mustela nigripes). Biological Conservation 89:121-129.

CARR, A., III. 1986. Introduction. Great Basin Naturalist Memoirs 8:1-7.

Chipault, J.G., D.E. Biggins, J.K. Detling, D.H. Long, AND R.M. Reich. 2012. Fine-scale habitat use of reintroduced black-footed ferrets on prairie dog colonies in New Mexico. Western North American Naturalist 72:216-227.

EADS, D.A. 2012. Notes on behaviors of free-ranging black-footed ferrets: Conata Basin, South Dakota, 2007-2009. Western North American Naturalist 72: $191-195$.

Eads, D.A., And D.E. Biggins. 2012. Patterns of surface burrow plugging in a colony of black-tailed prairie dogs occupied by black-footed ferrets. Western North American Naturalist 72:172-178.

Eads, D.A., D.E. Biggins, D. Marsh, J.J. MillsPaugh, AND T.M. LIVIERI. 2012a. Black-footed ferret digging activity in summer. Western North American Naturalist 72:140-147.

Eads, D.A., D.S. Jachowski, D.E. Biggins, T.M. Livieri, M.R. Matchett, and J.J. Millspaugh. 2012b. Resource selection models are useful in predicting finescale distributions of black-footed ferrets in prairie dog colonies. Western North American Naturalist 72:206-215

Eads, D.A., D.S. JaChowski, J.J. Millspaugh, and D.E. BIGGINS. 2012c. Importance of lunar and temporal conditions for spotlight surveys of adult black-footed ferrets. Western North American Naturalist 72: 179-190.

Eads, D.A., J.J. Millspaugh, D.E. Biggins, D.S. JachowSKI, AND T.M. LIVIERI. 2011a. Evaluation of a blackfooted ferret resource utilization function model. Journal of Wildlife Management 75:1155-1163.

Eads, D.A., J.J. Millspaugh, D.E. Biggins, T.M. Livieri, AND D.S. JACHOWSKI. 2011b. Post-breeding resource selection by adult black-footed ferrets in the Conata Basin, South Dakota. Journal of Mammalogy 92: 760-770.

Fagerstone, K.A., AND D.E. Biggins. 2011. Black-footed ferret areas of activity during late summer and fall at
Meeteetse, Wyoming. Journal of Mammalogy 92: 705-709.

Forrest, S.C., T.W. Clark, L. Richardson, and T.M CampBell III. 1985. Black-footed ferret habitat: some management and reintroduction considerations. Wyoming Bureau of Land Management Wildlife Technical Bulletin 2. 49 pp.

Houston, B.R., T.W. Clark, and S. Minta. 1986. Habitat suitability index model of the black-footed ferret: a method to locate transplant sites. Great Basin Naturalist Memoirs 8:99-114.

JACHOWSKI, D.J., AND J.M. LOCKHART. 2009. Reintroducing the black-footed ferret (Mustela nigripes) to the Great Plains of North America. Small Carnivore Conservation 41:58-64.

Linder, R.L., AND C.N. Hillman, Editors. 1973. Proceedings of the Black-footed Ferret and Prairie Dog Workshop, September 4-6, 1973, Rapid City, South Dakota. South Dakota State University, Brookings, SD.

Livieri, T.M., AND E.M. Anderson. 2012. Black-footed ferret home ranges in Conata Basin, South Dakota. Western North American Naturalist 72:196-205.

Matchett, R.M., D.E. Biggins, V. Carlson, B. Powell, AND T. ROCKE. 2010. Enzootic plague reduces blackfooted ferret (Mustela nigripes) survival in Montana. Vector-Borne and Zoonotic Diseases 10(1):27-35.

Miller, B., AND R.P. READING. 2012. Challenges to blackfooted ferret recovery: protecting prairie dogs. Western North American Naturalist 72:228-240.

Miller, B.J., G.E. Menkens, And S.H. Anderson. 1988. A field habitat model of black-footed ferrets. Pages 98-102 in Eighth Great Plains Wildlife Damage Control Workshop. U.S. Forest Service General Technical Report, RM-154.

Miller, S.W., AND J.F. Cully JR. 2001. Conservation of black-tailed prairie dogs (Cynomys ludovicianus). Journal of Mammalogy 82:889-893.

Oldemeyer, J.L., D.E. Biggins, B.J. Miller, and R. Crete, Editors. 1993. Management of prairie dog complexes for reintroduction of the black-footed ferret. U.S. Fish and Wildlife Service, Biological Report 93(13).

Rocke, T.E., J. Mencher, S.R. Smith, And A.M. FriedLANDER. 2004. Recombinant F1-V fusion protein protects black-footed ferrets (Mustela nigripes) against virulent Yersinia pestis infection. Journal of Zoo and Wildlife Medicine 35:142-146.

Rocke, T.E., N. Pussini, S.R. Smith, J. Williamson, B. POWELL, AND J.E. Osorio. 2010. Consumption of baits containing raccoon pox-based plague vaccines protects black-tailed prairie dogs (Cynomys ludovicianus). Vector-Borne and Zoonotic Diseases 10(1):53-58.

Roelle, J.E., B.J. Miller, J.L. Godbey, And D.E. BigGINS, EDITORS. 2006. Recovery of the black-footed ferret-progress and continuing challenges. United States Geological Survey Scientific Investigations Report 2005-5293.

SEAL, U.S., E.T. Thorne, M.A. Bogan, AND S.H. ANDERSON, EDITORS. 1989. Conservation biology and the blackfooted ferret. Yale University Press, New Haven CT.

WoOD, S.L., EDITOR. 1986. The black-footed ferret. Great Basin Naturalist Memoirs 8. Brigham Young University, Provo, UT. 